\title{
PURIFICATION OF WASTE COMBUSTION GAS IN HIGH TEMPERATURE REGIONS USING ECOFUNCTIONAL CERAMICS
}

\author{
K. SUZUKI ${ }^{1}$, S. NAGANO ${ }^{2} \&$ S. FUJITA ${ }^{3}$ \\ ${ }^{1}$ EcoTopia Science Institute, Nagoya University, Japan. \\ ${ }^{2}$ National Institute of Advanced Industrial Science and Technology (AIST), Japan \\ ${ }^{3}$ Toyota Central Research and Development Labs. Inc., Japan.
}

\begin{abstract}
Hydroxyl sodalite $\left(\mathrm{Na}_{8} \mathrm{Al}_{6} \mathrm{Si}_{6} \mathrm{O}_{24}(\mathrm{OH})_{2}\right)$ and hydrogrossular $\left(\mathrm{Ca}_{3} \mathrm{Al}_{2}\left(\mathrm{SiO}_{4}\right)_{0.8}(\mathrm{OH})_{8.8}\right)$ were investigated for the purpose of developing new ecofunctional ceramics with removal performance for toxic substances present in waste combustion gas. It was found that these materials had functions of chlorine fixation, copper fixation and the control of dioxin formation. Hydroxyl sodalite had nanometer-sized micropores ( $\beta$-cage) in the structure, and the chloride ions were fixed in the pores above $400^{\circ} \mathrm{C}$. The amount of chlorine that was fixed increased with increasing reaction temperature and was greatest, $7.3 \mathrm{wt} \%$, at $800^{\circ} \mathrm{C}$. The fixation of the copper progressed by the substitution with sodium ion, and the substitution quantity increased with increasing reaction temperature. The amount of copper fixed as $\mathrm{CuO}$ at $900^{\circ} \mathrm{C}$ was $10.5 \mathrm{wt} \%$. On the other hand, hydrogrossular changed to the mayenite phase $\left(\mathrm{Ca}_{12} \mathrm{Al}_{10} \mathrm{Si}_{4} \mathrm{O}_{35}\right)$ after heating to above $700^{\circ} \mathrm{C}$. Mayenite had micropores in the structure, which were fixed by the chloride ions. A drastic decrease in the concentration of dioxins was confirmed by introducing the ecofunctional ceramics, hydroxyl sodalite and hydrogrossular, in the municipal solid waste incineration.
\end{abstract}

Keywords: chlorine, copper fixation, dioxin, hydrogrossular, hydroxyl sodalite, oxidative catalyst, waste combustion gas.

\section{INTRODUCTION}

Recently, environmental pollution by dioxins has become a serious issue in Japan. It is important to purify the waste combustion gas discharged from the municipal solid waste incineration, because emissions of dioxins can be formed in the incineration of many forms of wastes [1-4]. To date, extensive research has been carried out on the removal of toxic substances present in waste combustion gas and the results of these studies have been put to practical use. Some of the examples are - the removal of $\mathrm{HCl}$ gas using calcium compounds such as lime and limestone [5-9], the adsorptive removal of dioxins using high surface area activated carbon [10-14], the decomposition removal of dioxins using catalysts [15-22] such as $\mathrm{V}_{2} \mathrm{O}_{5}-\mathrm{WO}_{3}-\mathrm{TiO}_{2}, \mathrm{CrO}_{\mathrm{x}}-\mathrm{TiO}_{2} / \mathrm{Al}_{2} \mathrm{O}_{3}$ and noble metals, and the elution prevention by stabilization of heavy metals adsorbed on fly ash. These purification technologies are processing technologies at low temperatures of about $200^{\circ} \mathrm{C}$ or at ambient temperatures because of the heat resistance of the bag filter. However, there are many advantages if the purification treatment of waste combustion gas could be realized in the high temperature region. Some of the advantages of high temperature purification include: (1) improvements in the efficiency and lifetime of the heat exchanger and the incinerator by controlling the high temperature corrosion caused by acid gases, (2) control of the formation of dioxins by the removal of dioxin precursors such as $\mathrm{HCl}$, hydrocarbons, chlorobenzene, phenol, unburned carbon, etc., and (3) recovering the fly ash with less pollution by controlling the formation of dioxins and by the removal of heavy metals. We have investigated that using ecofunctional ceramics, i.e. hydroxyl sodalite and hydrogrossular, in the high temperature range over $400^{\circ} \mathrm{C}, \mathrm{HCl}$, hydrocarbons and $\mathrm{CuCl}_{2}$ present in waste combustion gas could be removed in order to purify it and control the formation of dioxins. 


\section{EXPERIMENTAL METHOD}

\subsection{Sample preparation}

The hydroxyl sodalite $\left(\mathrm{Na}_{8} \mathrm{Al}_{6} \mathrm{Si}_{6} \mathrm{O}_{24}(\mathrm{OH})_{2}\right)$ was prepared using kaolinite $\left(\mathrm{Al}_{2}\left(\mathrm{Si}_{2} \mathrm{O}_{5}\right)(\mathrm{OH})_{4}\right)$ as the source of $\mathrm{Al}$ and $\mathrm{Si}$, and $\mathrm{NaOH}$ as the source of $\mathrm{Na}$. A mixed paste of kaolinite and $\mathrm{NaOH}$ was prepared in the molar ratio of $3: 10$. The ratio of $\mathrm{NaOH}$ added was considerably in excess than that theoretically required. The hydroxyl sodalite was synthesized by heat treatment $\left(100^{\circ} \mathrm{C}, 24 \mathrm{~h}\right)$ of the mixed paste in an oven. It was then washed with a large amount of distilled water to remove the excess $\mathrm{NaOH}$.

Hydrogrossular $\left(\mathrm{Ca}_{3} \mathrm{Al}_{2}\left(\mathrm{SiO}_{4}\right)_{0.8}(\mathrm{OH})_{8.8}\right)$ was synthesized by the hydrothermal treatment of a stoichiometric mixture of alumina-sol, amorphous silica and $\mathrm{CaO}$. The mixture was put in a Teflonlined stainless steel autoclave with distilled water. The water to solid ratio by weight was $12: 1$. The autoclave was placed in a temperature-controlled oven, and the temperature was controlled to increase from room temperature to $200^{\circ} \mathrm{C}$ in 2 hours. The mixture was then kept at $200^{\circ} \mathrm{C}$ for 15 hours. The solid product was separated by filtration and dried at $110^{\circ} \mathrm{C}$ for 24 hours.

\subsection{Reaction with $\mathrm{HCl}$ gas at high temperature}

\subsubsection{A small-sized fixed bed reactor}

A small-sized fixed bed reactor (Fig. 1) was used to examine the reaction between dry $\mathrm{HCl}$ gas, hydroxyl sodalite and hydrogrossular in the temperature range $400-900^{\circ} \mathrm{C}$. A quartz glass tube packed with a sample of $0.5 \mathrm{~g}$ was placed in a tubular electric furnace and the sample was heated to the desired temperature in flowing dry $\mathrm{N}_{2}$. After the sample reached the desired temperature, $\mathrm{HCl}$ gas of $1000 \mathrm{ppm}$ was flowed for 3 hours at a flow rate of $200 \mathrm{ml} / \mathrm{min}$.

\subsubsection{A medium-sized vertical reactor}

The experiment was started by heating the vertical tubular furnace to $700^{\circ} \mathrm{C}$ or $800^{\circ} \mathrm{C}$ with air flowing at $45 \mathrm{l} / \mathrm{min}$. The synthetic gas, $\mathrm{HCl}: 1000 \mathrm{ppm}, \mathrm{O}_{2}: 10 \mathrm{vol} \%, \mathrm{CO}_{2}: 10 \mathrm{vol} \%, \mathrm{H}_{2} \mathrm{O}: 10 \mathrm{vol} \%$, and $\mathrm{N}_{2}$ : balance, was introduced into the quartz glass reactor of diameter $0.1 \mathrm{~m}$ and length $4.5 \mathrm{~m}$.

Hydrogrossular was introduced into the reactor at the rate of $0.4,0.8,1.2$ and $1.6 \mathrm{~g} / \mathrm{min}$. A rough drawing and photograph of the reactor are shown in Figs 2 and 3 respectively.

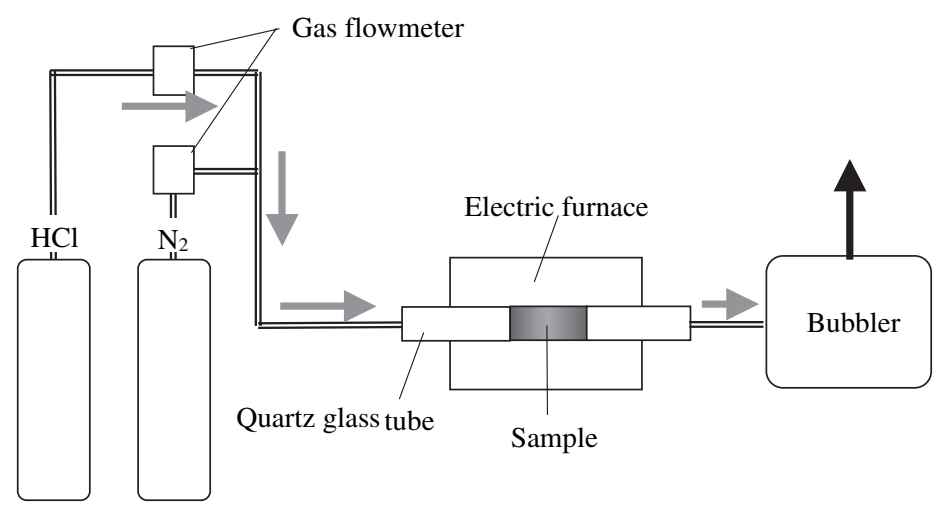

Figure 1: Rough drawing of a small-sized fixed bed reactor. 


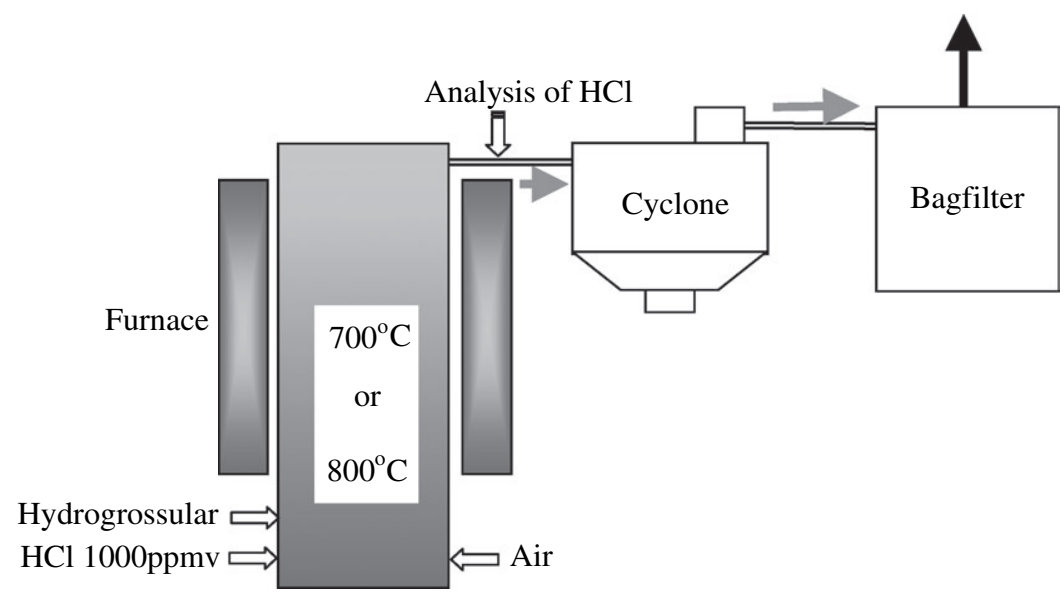

Figure 2: Rough drawing of a medium-sized vertical reactor.

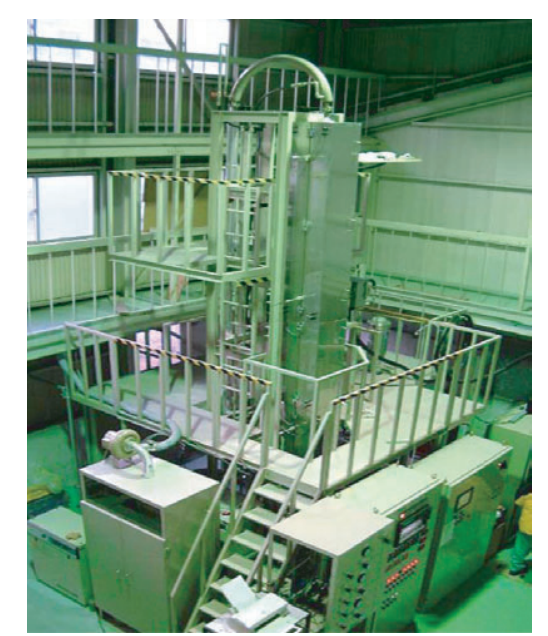

Figure 3: A photograph of a medium-sized vertical reactor.

\subsubsection{A large-sized fluidized bed combustor}

A rough drawing of the combustor used is shown in Fig. 4. Refuse derived fuel (RDF) made from a mixture of polyvinyl chloride, plastics waste and paper was burnt in a $1.2 \times 1.2 \times 9 \mathrm{~m}$ bubbling type fluidized bed combustor. The gas flow rate was $500 \mathrm{~N} \mathrm{~m}^{3} / \mathrm{h}$ and the temperature of combustion was $750 \pm 50^{\circ} \mathrm{C}$. The concentration of $\mathrm{HCl}$ was continuously recorded. Hydroxyl sodalite and hydrogrossular powder were introduced into the combustor at $6.2 \mathrm{~kg} / \mathrm{h}$, respectively.

\subsection{Reaction with $\mathrm{CuCl}_{2}$ at high temperature}

The reactor is shown in Fig. 5. Two alumina boats, one filled with $0.5 \mathrm{~g}$ hydroxyl sodalite and the other containing $0.5 \mathrm{~g} \mathrm{CuCl}_{2}$, were loaded into the tubular electric furnace. The reaction of the hydroxyl 
Sampling point (a)

Analysis of Dioxin, $\mathrm{CO}$ and $\mathrm{O}_{2}\left(\right.$ at $700^{\circ} \mathrm{C}$ )

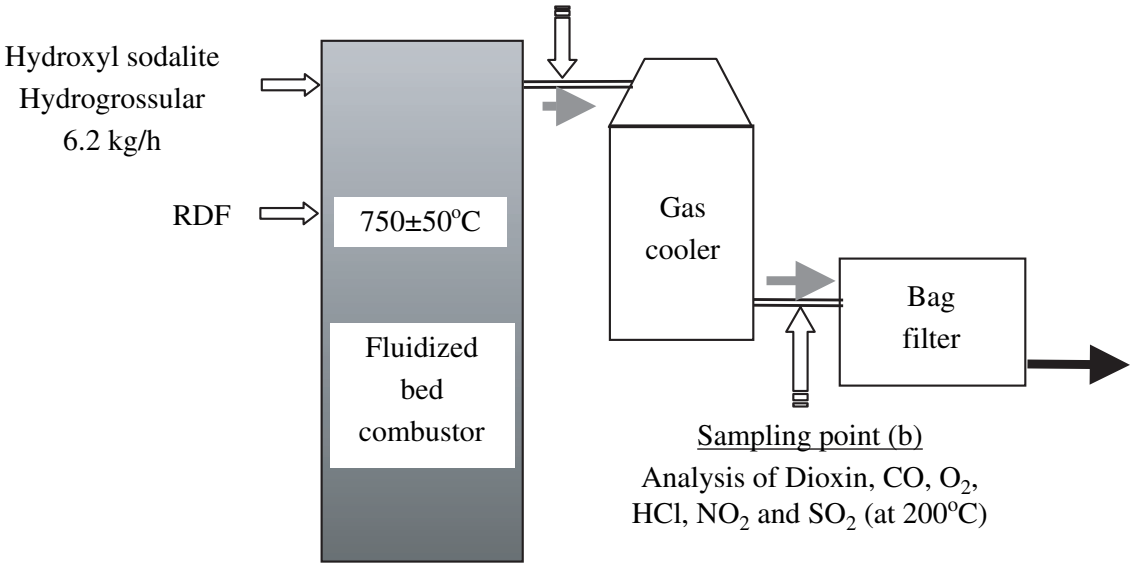

Figure 4: Rough drawing of a large-sized fluidized bed combustor.

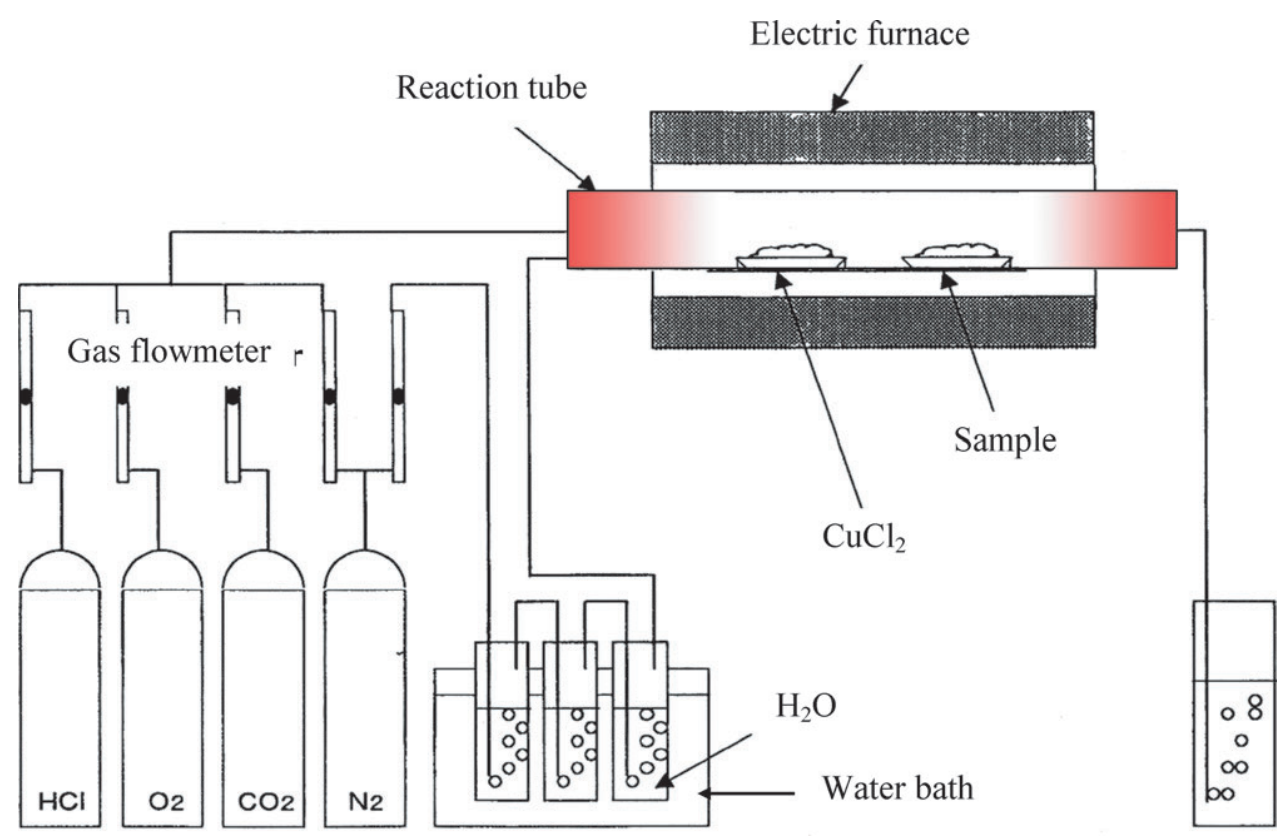

Figure 5: Rough drawing of a reactor for examining the reaction between the sample and $\mathrm{CuCl}_{2}$.

sodalite and $\mathrm{CuCl}_{2}$ was carried out in the temperature range $400-900^{\circ} \mathrm{C}$, with a mixed gas consisting of $10 \mathrm{vol} \% \mathrm{O}_{2}, 10 \mathrm{vol} \% \mathrm{CO}_{2}, 10 \mathrm{vol} \% \mathrm{H}_{2} \mathrm{O}, 1000 \mathrm{ppm} \mathrm{HCl}$ and $\mathrm{N}_{2}$ (balance) flowing through the furnace. The flow rate of the mixed gas was $500 \mathrm{ml} / \mathrm{min}$, and the reaction time was one hour. After the reaction was complete, the hydroxyl sodalite recovered was analyzed by XRF after washing with distilled water. 


\subsection{Measurement}

Thermal decomposition behavior, crystal structure and chemical composition of the samples before and after the reaction were examined by TG-DTA, XRD and XRF, respectively.

\section{RESULTS AND DISCUSSION}

3.1 Fixation performance of $\mathrm{Cl}^{-}$using a small-sized fixed bed reactor

\subsubsection{Hydroxyl sodalite}

When hydroxyl sodalite reacts with $\mathrm{HCl}$ gas, $\mathrm{OH}^{-}$ions are replaced with $\mathrm{Cl}^{-}$ions in the $\beta$-cage of the sodalite structure and it becomes sodalite $\left(\mathrm{Na}_{8} \mathrm{Al}_{6} \mathrm{Si}_{6} \mathrm{O}_{24} \mathrm{Cl}_{2}\right.$ ) (eqn (1)) [23]. The lattice constant $\left(\mathrm{a}_{0}\right)$ of the sodalite structure increases from 8.86 to $9.04 \AA$ due to the substitution of smaller $\mathrm{OH}^{-}$(ionic radius: $1.32 \AA$ ) by the larger $\mathrm{Cl}^{-}$ion $(1.81 \AA$ ).

$$
\mathrm{Na}_{8} \mathrm{Al}_{6} \mathrm{Si}_{6} \mathrm{O}_{24}(\mathrm{OH})_{2}+2 \mathrm{HCl} \rightarrow \mathrm{Na}_{8} \mathrm{Al}_{6} \mathrm{Si}_{6} \mathrm{O}_{24} \mathrm{Cl}_{2}+2 \mathrm{H}_{2} \mathrm{O}
$$

The relationship between the amount of $\mathrm{Cl}^{-}$fixed in the sodalite structure and the reaction temperature is shown in Fig. 6. The weight ratio of the $\mathrm{Cl}^{-}$ion was measured by XRF, and the weight ratio to the sodalite (wt\%) was regarded as the amount of $\mathrm{Cl}^{-}$fixed. The amount of $\mathrm{Cl}^{-}$fixed increases with increasing reaction temperature, however it drastically decreases after reaching the highest value at $800^{\circ} \mathrm{C}$. Consequently, the amount of $\mathrm{Cl}^{-}$fixed at $900^{\circ} \mathrm{C}$ was almost zero. The amount of $\mathrm{Cl}^{-}$fixed at $800^{\circ} \mathrm{C}$ was $7.3 \mathrm{wt} \%$, and this value corresponds to the $\mathrm{Cl}^{-}$weight ratio in the sodalite. At $900^{\circ} \mathrm{C}$, the crystal phase changed from the sodalite structure to carnegieite $\left(\mathrm{NaAlSiO}_{4}\right)$.

According to the measurement result of TG-DTA of hydroxyl sodalite, the dehydration reaction for $\mathrm{OH}^{-}$occurred at $260^{\circ} \mathrm{C}$ (eqn (2)) with the endothermic peak, and hydroxyl sodalite underwent a phase change to carnegieite at $877^{\circ} \mathrm{C}$ (eqn (3)) with the exothermic peak. Carnegieite cannot react with $\mathrm{HCl}$ at all.

$$
\begin{gathered}
\mathrm{Na}_{8} \mathrm{Al}_{6} \mathrm{Si}_{6} \mathrm{O}_{24}(\mathrm{OH})_{2} \rightarrow \mathrm{Na}_{8} \mathrm{Al}_{6} \mathrm{Si}_{6} \mathrm{O}_{25}+\mathrm{H}_{2} \mathrm{O} \text { at } 260^{\circ} \mathrm{C} \\
\mathrm{Na}_{8} \mathrm{Al}_{6} \mathrm{Si}_{6} \mathrm{O}_{25} \rightarrow 6 \mathrm{NaAlSiO}_{4}+\mathrm{Na}_{2} \mathrm{O} \text { at } 877^{\circ} \mathrm{C}
\end{gathered}
$$

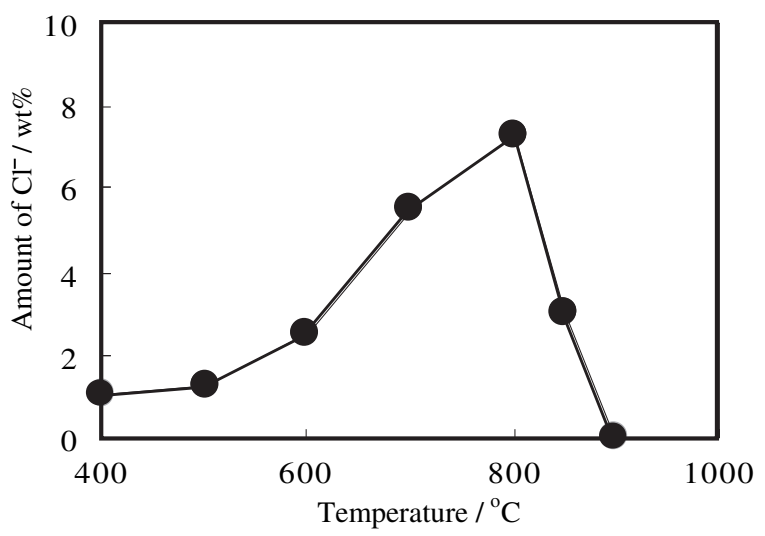

Figure 6: The relationship between the amount of $\mathrm{Cl}^{-}$fixed in the sodalite structure and the reaction temperature. 
3.1.2 Hydrogrossular

From the TG-DTA measurement of hydrogrossular, the following fact became clear: the endothermic peaks at $320^{\circ} \mathrm{C}$ and $680^{\circ} \mathrm{C}$ recorded in DTA could be attributed to the release of $\mathrm{OH}$ radical. The hydrogrossular phase is transformed into anhydrous mayenite $\left(\mathrm{Ca}_{12} \mathrm{Al}_{10} \mathrm{Si}_{4} \mathrm{O}_{35}\right)$ through the hydrous mayenite $\left(\mathrm{Ca}_{12} \mathrm{Al}_{10} \mathrm{Si}_{4} \mathrm{O}_{32}(\mathrm{OH})_{6}\right)$ phase. The ideal phase transition of hydrogrossular with increasing temperatures has been described as shown in eqns (4) and (5), respectively [24, 25].

$$
\begin{gathered}
5 \mathrm{Ca}_{3} \mathrm{Al}_{2}\left(\mathrm{SiO}_{4}\right)_{0.8}(\mathrm{OH})_{8.8} \rightarrow \mathrm{Ca}_{12} \mathrm{Al}_{10} \mathrm{Si}_{4} \mathrm{O}_{32}(\mathrm{OH})_{6}+3 \mathrm{CaO}+19 \mathrm{H}_{2} \mathrm{O} \text { at } 320^{\circ} \mathrm{C} \\
\mathrm{Ca}_{12} \mathrm{Al}_{10} \mathrm{Si}_{4} \mathrm{O}_{32}(\mathrm{OH})_{6} \rightarrow \mathrm{Ca}_{12} \mathrm{Al}_{10} \mathrm{Si}_{4} \mathrm{O}_{35}+3 \mathrm{H}_{2} \mathrm{O} \text { at } 680^{\circ} \mathrm{C}
\end{gathered}
$$

The XRD patterns of hydrogrossular reacting with $\mathrm{HCl}$ were measured under ambient conditions after cooling from each reaction temperature to room temperature. At the reaction temperature above $400^{\circ} \mathrm{C}$, the main phase recorded was wadalite $\left(\mathrm{Ca}_{12} \mathrm{Al}_{10} \mathrm{Si}_{4} \mathrm{O}_{32} \mathrm{Cl}_{6}\right)$, and a second phase corresponding to $\mathrm{CaCl}_{2} \cdot 2 \mathrm{H}_{2} \mathrm{O}$ was also observed. Since $\mathrm{CaCl}_{2}$ is highly hygroscopic, it could take up moisture and form $\mathrm{CaCl}_{2} \cdot 2 \mathrm{H}_{2} \mathrm{O}$. The chemical composition of the sample, after removing the second phase $\left(\mathrm{CaCl}_{2} \cdot 2 \mathrm{H}_{2} \mathrm{O}\right)$ by washing in distilled water, was $\mathrm{Ca}_{12} \mathrm{Al}_{9.9} \mathrm{Si}_{4.05} \mathrm{O}_{32} \mathrm{Cl}_{5.9}$ (Wadalite), which had a chlorine content of $13.2 \mathrm{wt} \%$. The $\mathrm{HCl}$ gas was efficiently removed from the inlet gas as $\mathrm{Ca}_{12} \mathrm{Al}_{9.9} \mathrm{Si}_{4.05} \mathrm{O}_{32} \mathrm{Cl}_{5.9}$ and $\mathrm{CaCl}_{2}$ above $400^{\circ} \mathrm{C}$.

On the basis of the results obtained, the reaction formula of hydrogrossular and $\mathrm{HCl}$ is shown in eqns (6) and (7) $[24,25]$.

$$
\begin{aligned}
& \mathrm{Ca}_{12} \mathrm{Al}_{10} \mathrm{Si}_{4} \mathrm{O}_{32}(\mathrm{OH})_{6}+3 \mathrm{CaO}+12 \mathrm{HCl} \rightarrow \mathrm{Ca}_{12} \mathrm{Al}_{10} \mathrm{Si}_{4} \mathrm{O}_{32} \mathrm{Cl}_{6} \\
&+3 \mathrm{CaCl}_{2}+9 \mathrm{H}_{2} \mathrm{O} \sim 400-650^{\circ} \mathrm{C} \\
& \mathrm{Ca}_{12} \mathrm{Al}_{10} \mathrm{Si}_{4} \mathrm{O}_{35}+3 \mathrm{CaO}+12 \mathrm{HCl} \rightarrow \mathrm{Ca}_{12} \mathrm{Al}_{10} \mathrm{Si}_{4} \mathrm{O}_{32} \mathrm{Cl}_{6}+3 \mathrm{CaCl}_{2}+6 \mathrm{H}_{2} \mathrm{O} \quad \text { above } 700^{\circ} \mathrm{C}
\end{aligned}
$$

3.2 Hydrogen chloride removal performance using a medium-sized vertical reactor

In the medium-sized vertical reactor with flowing synthetic gases, the concentration of $\mathrm{HCl}$ at $700^{\circ} \mathrm{C}$ and $800^{\circ} \mathrm{C}$ with the introduction of hydrogrossular was $\sim 0.4-1.6 \mathrm{~g} / \mathrm{min}$. The $\mathrm{HCl}$ was efficiently removed from the inlet gas, and the concentration decreased with increasing the concentration in the inlet. In Fig. 7 the result of introducing hydrogrossular of $0.4 \mathrm{~g} / \mathrm{min}$ (a) and $1.6 \mathrm{~g} / \mathrm{min}$ (b) is shown. The amount of $\mathrm{HCl}$ removed at $800^{\circ} \mathrm{C}$ was only half the quantity compared to that removed at $700^{\circ} \mathrm{C}$. This result could be attributed to the fact that at $800^{\circ} \mathrm{C}, \mathrm{H}_{2} \mathrm{O}$ suppresses only $\mathrm{CaCl}_{2}$ formation but not the wadalite formation [26-28].

\subsection{Reaction of hydroxyl sodalite and $\mathrm{CuCl}_{2}$}

After the reaction of hydroxyl sodalite and $\mathrm{CuCl}_{2}$ in the temperature range $400-900^{\circ} \mathrm{C}$ was complete, the hydroxyl sodalite recovered was analyzed by XRF after washing with distilled water. The result of the analysis is shown in Fig. 8 and Table 1. It can be seen that the $\mathrm{Al}_{2} \mathrm{O}_{3}$ and $\mathrm{SiO}_{2}$ contents before and after the reaction are almost the same. However, the content of $\mathrm{Na}_{2} \mathrm{O}$ decreases with increasing reaction temperature. It is also observed that the $\mathrm{CuO}$ content increases with the decreasing $\mathrm{Na}_{2} \mathrm{O}$ content exhibiting a reverse correlation as shown in Fig. 8. The result of a similar experiment using sodalite $\left(\mathrm{Na}_{8} \mathrm{Al}_{6} \mathrm{Si}_{6} \mathrm{O}_{24} \mathrm{Cl}_{2}\right)$ showed that the $\mathrm{CuO}$ content at $700^{\circ} \mathrm{C}$ was $5.0 \mathrm{wt} \%$, which is almost equal to that observed using hydroxyl sodalite $(5.3 \mathrm{wt} \%)$. From these results, it can be concluded 

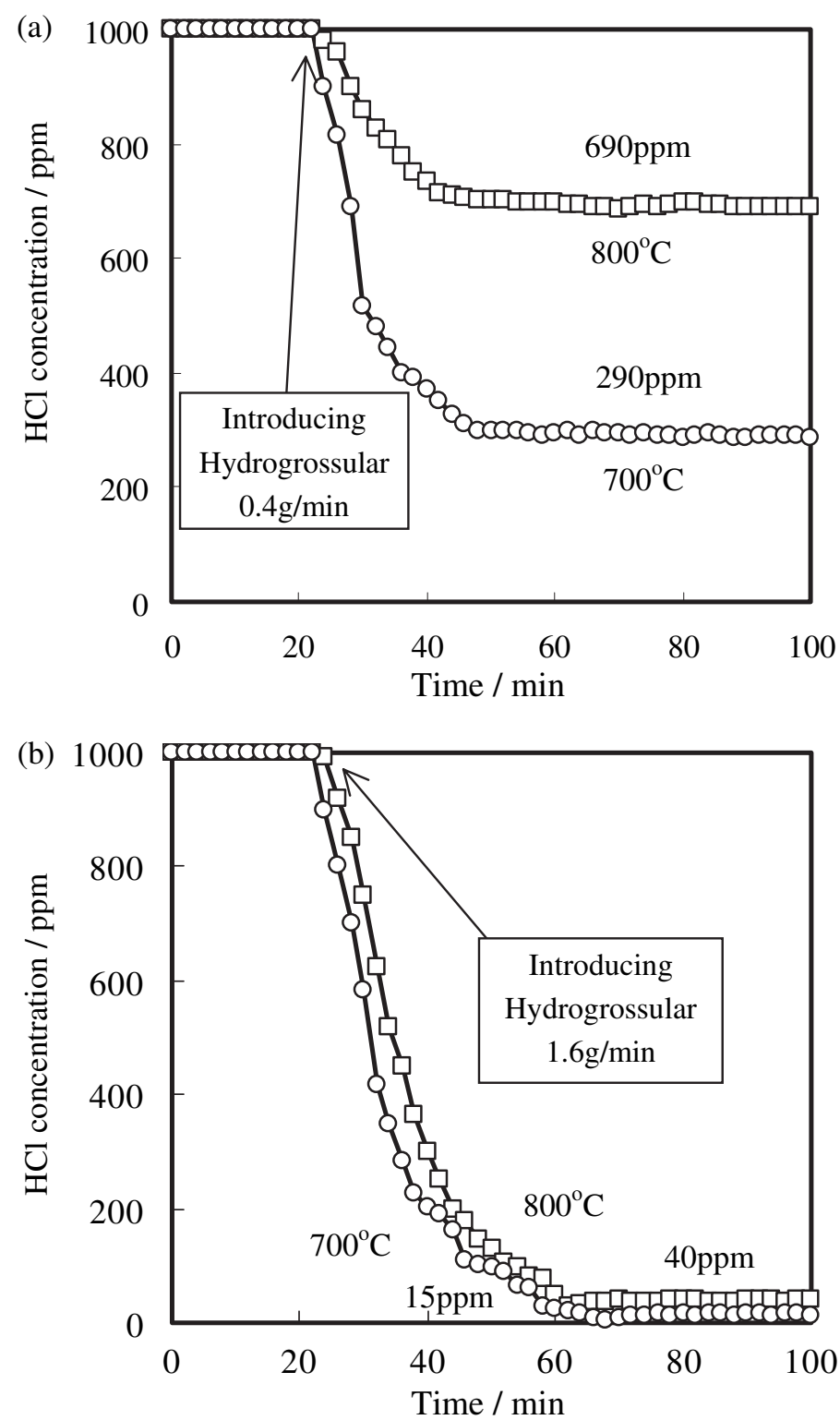

Figure 7: The effect of hydrogrossular introducing of $0.4 \mathrm{~g} / \mathrm{min}$ (a) and $1.6 \mathrm{~g} / \mathrm{min}$ (b) for $\mathrm{HCl}$ concentration reduction.

that hydroxyl sodalite and sodalite could react with $\mathrm{CuCl}_{2}$ at high temperatures over $400^{\circ} \mathrm{C}$, and $\mathrm{Na}$ cations in hydroxyl sodalite and sodalite could be substituted by $\mathrm{Cu}$ cations.

Although the existence of $\mathrm{Cl}$ in hydroxyl sodalite is evidenced, it is unclear if all the $\mathrm{Cl}^{-}$ions are captured from $\mathrm{HCl}$ or also from $\mathrm{CuCl}_{2}$. In any case, the existence of $\mathrm{CuCl}_{2}$ is very important in the formation of dioxins. $\mathrm{CuCl}_{2}$ present in fly ash fulfils the role as a catalyst for the formation of dioxins [29-31]. Therefore, it seems to be possible to realize the control of the formation of dioxins by removing $\mathrm{CuCl}_{2}$ at high temperature. 


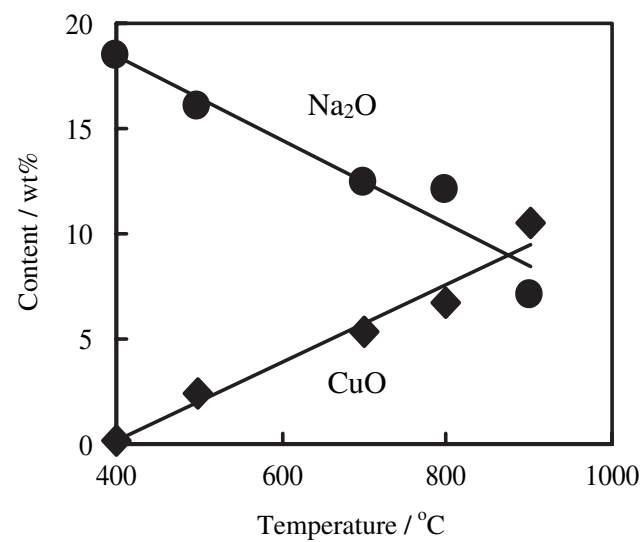

Figure 8: The relationship between the $\mathrm{Na}_{2} \mathrm{O}$ and $\mathrm{CuO}$ content in hydroxyl sodalite and the reaction temperature.

Table 1: Analysis result of hydroxyl sodalite after reaction with $\mathrm{CuCl}_{2}$.

\begin{tabular}{lcccccc}
\hline & & \multicolumn{5}{c}{ Analysis value (wt\%) } \\
\cline { 3 - 7 } $\begin{array}{l}\text { Reaction } \\
\text { temperature }\left({ }^{\circ} \mathrm{C}\right)\end{array}$ & $\begin{array}{c}\text { Reaction } \\
\text { time (hour) }\end{array}$ & $\mathrm{CuO}$ & $\mathrm{Na}_{2} \mathrm{O}$ & $\mathrm{Cl}$ & $\mathrm{Al}_{2} \mathrm{O}_{3}$ & $\mathrm{SiO}_{2}$ \\
\hline 400 & 1 & 0.2 & 18.4 & 0.4 & 32.2 & 48.8 \\
500 & 1 & 2.4 & 16.0 & 0.7 & 32.3 & 48.5 \\
700 & 1 & 5.3 & 12.5 & 3.2 & 31.1 & 46.5 \\
800 & 1 & 6.7 & 12.0 & 3.3 & 30.9 & 45.5 \\
900 & 1 & 10.5 & 7.1 & 1.1 & 31.6 & 48.0 \\
\hline
\end{tabular}

3.4 Waste combustion gas purification performance using a large-sized fluidized bed combustor

Table 2 summarizes the composition of waste combustion gas from RDF in the large-sized fluidized bed combustor. After introducing hydroxyl sodalite or hydrogrossular, the $\mathrm{HCl}$ concentration decreased from $174 \mathrm{ppm}$ to $13 \mathrm{ppm}$ for the former and to $35 \mathrm{ppm}$ for the latter.

The concentration of dioxins at the sampling point (a) with the introduction of hydrogrossular $\left(1.2 \mathrm{ng}-\mathrm{TEQ} / \mathrm{N} \mathrm{m}^{3}\right)$ is significantly higher than that observed in the absence of hydrogrossular $\left(0.21 \mathrm{ng}-\mathrm{TEQ} / \mathrm{N} \mathrm{m}^{3}\right)$. A more oxidizing condition for combustion, as a higher $\mathrm{CO}$ concentration (1010 ppm versus $687 \mathrm{ppm}$ ) suggested, could be a possible cause for the reduction in the formation of dioxins. It has been noted that the formation of dioxins at the inlet of the gas cooler is suppressed more effectively with the use of hydrogrossular than without it, although the combustion conditions differ from each other. This suppression should result from capturing $\mathrm{Cl}^{-}$with hydrogrossular at high temperatures, by which the formation of digoxins could be avoided. It is also probable that the oxidative decomposition of dioxins would occur even if it is formed during the combustion of RDF. This is because mayenite $\left(\mathrm{Ca}_{12} \mathrm{Al}_{10} \mathrm{Si}_{4} \mathrm{O}_{35}\right)$, which is formed by the thermal decomposition of hydrogrossular, has the ability for the oxidative decomposition of chlorinated compounds to $\mathrm{CO}_{2}$ and $\mathrm{H}_{2} \mathrm{O}$ probably due to the superoxide anion $\left(\mathrm{O}_{2}^{-}\right)$and peroxide anion $\left(\mathrm{O}_{2}^{2-}\right)$ present in it $[32,33]$. 
Table 2: Composition of waste combustion gas.

\begin{tabular}{lccc}
\hline & Blank & Hydroxyl sodalite & Hydrogrossular \\
\hline Sampling point $(a)$ & & & \\
Dioxin $\left(\mathrm{ng}-\mathrm{TEQ} / \mathrm{N} \mathrm{m}^{3}\right)$ & 0.21 & 0.06 & 1.2 \\
$\mathrm{O}_{2}(\%)$ & 2.4 & 3.7 & 2.3 \\
$\mathrm{CO}(\mathrm{ppm})$ & 687 & 999 & 1010 \\
Sampling point $(b)$ & & & \\
Dioxin $\left(\mathrm{ng}-\mathrm{TEQ} / \mathrm{N} \mathrm{m}^{3}\right)$ & 12 & 4.2 & 4.6 \\
$\mathrm{HCl}(\mathrm{ppm})$ & 174 & 13 & 35 \\
$\mathrm{O}_{2}(\%)$ & 3.2 & 3.7 & 2.3 \\
$\mathrm{CO}(\mathrm{ppm})$ & 741 & 1020 & $>1100$ \\
$\mathrm{SO}_{2}(\mathrm{ppm})$ & 0 & 0 & 0 \\
$\mathrm{NO}_{2}(\mathrm{ppm})$ & 18 & 11 & 21 \\
\hline
\end{tabular}

On the other hand, since hydroxyl sodalite also has the possibility of occluding the oxygen radicals, it is considered that a similar phenomenon occurs even in hydroxyl sodalite. Research is in progress to clarify this. In any case, it has been confirmed that the amount of dioxins could be decreased by simply introducing hydrogrossular or hydroxyl sodalite into a conventional combustor without any modification.

\section{CONCLUSIONS}

New ecofunctional ceramics, namely hydroxyl sodalite and hydrogrossular have been investigated in the present study for the abatement of $\mathrm{HCl}$ and dioxins from waste combustion gas. As a result of a plant scale test in the incinerator, it has been demonstrated that these new ecofunctional ceramics could decrease the concentrations of $\mathrm{HCl}$ at high temperatures and dioxins contained in waste combustion gas. In addition, it has been found that hydroxyl sodalite fixed copper in vapor phase at high temperatures. The above results confirm that the new ecofunctional ceramics are effective for the purification of waste combustion gas in the high temperature region without recovery of the waste incinerator. Generally, the recovery of the waste incinerator is very expensive and the presence of the ecofunctional ceramics would make the recovery unnecessary.

\section{REFERENCES}

[1] Choudhry, G., Olie, K. \& Hutzinger, O., Chlorinated Dioxins and Related Compounds-Impact on the Environment, Pergamon Press: New York, pp. 275-301, 1982.

[2] Addink, R. \& Olie, K., Mechanisms of formation and destruction of polychlorinated dibenzop-dioxins and dibenzofurans in heterogeneous systems. Environmental Science \& Technology, 29, pp. 1425-1435, 1995.

[3] Gordon, M., Dioxin characterisation, formation and minimisation during municipal solid waste (MSW) incineration: review. Chemical Engineering Journal, 86, pp. 343-368, 2002.

[4] Stanmore, B.R., The formation of dioxins in combustion systems. Combustion and Flame, 136, pp. 398-427, 2004.

[5] Daoudi, M. \& Walters, J.K., A thermogravimetric study of the reaction of hydrogen chloride gas with calcined limestone: determination of kinetic parameters. Chemical Engineering Journal, 47, pp. 1-9, 1991. 
[6] Daoudi, M. \& Walters, J.K., The reaction of $\mathrm{HCl}$ gas with calcined commercial limestone particles: the effect of particle size. Chemical Engineering Journal, 47, pp. 11-16, 1991.

[7] Mura, G. \& Lallai, A., On the kinetics of dry reaction between calcium oxide and gas hydrochloric acid. Chemical Engineering Science, 47, pp. 2407-2411, 1992.

[8] Uchida, T., Itoh, I. \& Harada, K., Immobilization of heavy metals contained in incinerator fly ash by application of soluble phosphate - treatment and disposal cost reduction by combined use of 'high specific surface area lime'. Waste Management, 16, pp. 475-481, 1996.

[9] Bodénan, F. \& Deniard, Ph., Characterization of flue gas cleaning residues from European solid waste incinerators: assessment of various Ca-based sorbent processes. Chemosphere, 51, pp. 335-347, 2003.

[10] Tejima, H., Nakagawa, I., Shinoda, T. \& Maeda, I., PCCDs/PCDFs reduction by good combustion technology and fabric filter with/without activated carbon injection. Chemosphere, 32, pp. 169-175, 1996.

[11] Furubayashi, M., Shinohara, R. \& Nagai, K., Study of dioxin removal by activated carbon. Kagaku Kogaku Ronbunshu, 27, pp. 236-242, 2001 (in Japanese, with English abstract).

[12] Okajima, S., Kojima, T., Ueoka, S. \& Ozaki, H., Fixed-bed adsorption of polychlorinated dibenzo- $p$-dioxins and dibenzofurans from the flue gas of a municipal solid waste incinerator. Organohalogen Compounds, 54, pp. 193-196, 2001.

[13] Furubayashi, M. \& Nagai, K., Estimation of dioxins removal efficiency by activated carbon. Kagaku Kogaku Ronbunshu, 30, pp. 54-64, 2004 (in Japanese, with English abstract).

[14] Everaert, K. \& Baeyens, J., Removal of PCDD/F from flue gases in fixed or moving bed adsorbers. Waste Management, 24, pp. 37-42, 2004.

[15] Ok, G., Hanai, Y. \& Katou, T., Decomposition of chlorinated dioxins, odorous compounds and $\mathrm{NO}_{\mathrm{x}}$ from MSW incineration plant by oxidizing catalyst. Chemosphere, 26, pp. 2167-2172, 1993.

[16] Fujii, T., Murakawa, T., Maeda, N., Kondo, M., Nagai, K., Hama, T. \& Ota, K., Removal technology of PCDDs/PCDFs in flue gas from MSW incinerators by fabric bag filter and SCR system. Chemosphere, 29, pp. 2067-2070, 1994.

[17] Ide, Y., Kashiwabara, K., Okada, S., Mori, T. \& Hara, M., Catalytic decomposition of dioxin from MSW incinerator flue gas. Chemosphere, 32, pp. 189-198, 1996.

[18] Weber, R., Sakurai, T. \& Hagenmaier, H., Low temperature decomposition of PCDD/ PCDF, chlorobenzenes and PAHs by $\mathrm{TiO}_{2}$-based $\mathrm{V}_{2} \mathrm{O}_{5}-\mathrm{WO}_{3}$ catalysts. Applied Catalysis B: Environmental, 20, pp. 249-256, 1999.

[19] Liu, Y., Luo, M., Wei, Z., Xin, Q., Ying, P. \& Li, C., Catalytic oxidation of chlorobenzene on supported manganese oxide catalysts. Applied Catalysis B: Environmental, 29, pp. 61-67, 2001.

[20] Yim, S.D., Koh, D.J. \& Nam, I.S., A pilot plant study for catalytic decomposition of PCDDs/ PCDFs over supported chromium oxide catalysts. Catalysis Today, 75, pp. 269-276, 2002.

[21] Ukisu, Y. \& Miyadera, T., Dechlorination of polychlorinated dibenzo-p-dioxins catalyzed by noble metal catalysts under mild conditions. Chemosphere, 46, pp. 507-510, 2002.

[22] Okumura, M., Akita, T., Haruta, M., Wang, X., Kajikawa, O. \& Okada, O., Multi-component noble metal catalysts prepared by sequential deposition precipitation for low temperature decomposition of dioxin. Applied Catalysis B: Environmental, 41, pp. 43-52, 2003.

[23] Suzuki, K., Shibasaki, Y., Fujita, S., Yamasaki, T., Ogawa, N., Fukuda, T. \& Sataka, S., Hydrogen chloride removal by hydroxyl sodalite or hydrogrossular at high temperature. Advances in Science and Technology, 34, pp. 345-356, 2003.

[24] Fujita, S., Suzuki, K., Ohkawa, M., Shibasaki, Y. \& Mori, T., Reaction of hydrogrossular with hydrogen chloride gas at high temperature. Chemistry of Materials, 13, pp. 2523-2527, 2001. 
[25] Fujita, S., Suzuki, K., Mori, T. \& Shibasaki, Y., A new technique to remove hydrogen chloride gas at high temperature using hydrogrossular. Industrial \& Engineering Chemistry Research, 42, pp. 1023-1027, 2003.

[26] Brian, K.G., Wojciech, J. \& Leonard, A.S., Reaction kinetics of Ca-based sorbents with HCl. Industrial \& Engineering Chemistry Research, 31, pp. 2437-2446, 1992.

[27] Barin, I., Sauert, F., Shultze-Rhonhof, E. \& Wang, S., Thermochemical Data of Pure Substances, VCH Publishers: Weinheim, Germany, 1989.

[28] Duo, W., Sevill, J.P.K., Kirkby, N.F. \& Clift, R., Formation of product layers in solid-gas reactions for removal of acid gases. Chemistry of Engineering Science, 49, pp. 4429-4442, 1994.

[29] Gullett, B.K., Bruce, K.R., Beach, L.O. \& Drago, A.M., Mechanistic steps in the production of PCDD during waste combustion. Chemosphere, 25, pp. 1387-1392, 1992.

[30] Ismo, H., Kari, T. \& Juhani, R., Formation of aromatic chlorinated compounds catalyzed by copper and iron. Chemosphere, 34, pp. 2649-2662, 1997.

[31] Hatanaka, T., Kitajima, A. \& Takeuchi, M., Role of copper chloride in the formation of polychlorinated dibenzo-p-dioxins and dibenzofurans during incineration. Chemosphere, 57, pp. 73-79, 2004.

[32] Fujita, S., Suzuki, K., Ohkawa, M., Mori, T., Iida, Y., Miwa, Y., Masuda, H., \& Shimada, S., Oxidative destruction of hydrocarbons over a new zeolite-like $\mathrm{Ca}_{12} \mathrm{Al}_{10} \mathrm{Si}_{4} \mathrm{O}_{35}$ crystal including $\mathrm{O}_{2}^{-}$and $\mathrm{O}_{2}^{2-}$ radicals. Chemistry of Materials, 15, pp. 255-263, 2003.

[33] Fujita, S., Ohkawa, M., Suzuki, K., Nakano, H., Mori, T. \& Masuda, H., Controlling the quantity of radical oxygen occluded in a new aluminum silicate with nanopores. Chemistry of Materials, 15, pp. 4879-4881, 2003. 